\title{
Pengaruh Penerapan Model Pembelajaran Means Ends Analysis terhadap Kemampuan Menalar Deduktif Mahasiswa Ditinjau dari Kemampuan Representasi Matematis
}

\author{
Dwi Antari Wijayanti ${ }^{1 *}$, Pinta Deniyanti ${ }^{2}$ \\ ${ }^{1,2}$ Universitas Negeri Jakarta \\ *dwi-antari@unj.ac.id
}

Diterima: Agustus 2019. Disetujui: Desember 2019. Dipublikasikan: Januari 2020

\begin{abstract}
ABSTRAK
Penelitian ini bertujuan untuk mengetahui pengaruh penerapan model pembelajaran means ends analysis (MEA) terhadap kemampuan menalar deduktif mahasiswa ditinjau dari kemampuan representasi matematis. Metode yang digunakan dalam penelitian ini adalah menggunakan quasi experiment dengan desain penelitian posttest only group control design. subyek penelitian sebagai populasi dalam penelitian adalah seluruh mahasiswa program studi pendidikan matematika FMIPA UNJ yang mengambil mata kuliah geometri euclid. Teknik yang digunakan dalam pengambilan sampel adalah multistage random sampling. Sedangkan pengambilan data menggunakan instrumen tes kemampuan representasi matematis, tes kemampuan menalar deduktif, teknik analisis data menggunakan two-way ANOVA. Hasil penelitian menunjukkan bahwa kemampuan menalar deduktif mahasiswa yang mendapat perlakuan model pembelajaran MEA secara keseluruhan lebih tinggi dibanding mahasiswa yang diajar dengan pembelajaran konvensional. Selain itu juga terdapat interaksi antara model pembelajaran dan kemampuan representasi matematis yang berpengaruh signifikan terhadap kemampuan menalar deduktif. Dalam penelitian ini ditemukan bahwa kemampuan menalar deduktif mahasiswa yang memiliki kemampuan representasi matematis tinggi yang mendapat perlakuan model pembelajaran MEA lebih tinggi dibanding siswa diajar dengan pembelajaran konvensional, sedangkan pada kelomok siswa yang memiliki kemampuan representasi matematis rendah, terdapat perbedaan kemampuan menalar deduktif yang signifikan antara siswa yang mendapat perlakuan model pembelajaran MEA dan siswa yang diajar dengan pembelajaran konvensional.
\end{abstract}

Kata kunci: model pembelajaran MEA, kemampuan menalar deduktif, kemampuan awal representasi.

ABSTRACT

The objective of this research is to investigate the effect of applying means-ends analysis (MEA) learning model on students deductive abilities in terms of mathematical representation abilities. The method adopted in this study is a quasi-experiment with a research design posttest only group control design. The population was all students who took Euclid geometry course in Mathematics Education Study Program, Universitas Negeri Jakarta. Multistage random sampling is used, while the data collection of mathematical representation ability test instruments, deductive reasoning ability tests, data analysis techniques using two-way ANOVA. The results showed that students deductive ability treated by MEA learning model was overall higher than students who treated with conventional learning. Also, there is an interaction between the learning model and the ability of mathematical representation on deductive reasoning ability. It was also found that deductive reasoning ability of students who have high mathematical representation ability treated by MEA learning models was higher than students taught with conventional learning. While students who had low mathematical representation abilities, there were significant differences in deductive reasoning abilities between students who received treated by MEA learning model and students taught with conventional learning.

Keywords: means ends analysis (MEA) learning model, deductive reasoning ability, initial representation ability.

How to Cite: Wijayanti, D. A. \& Deniyanti, P. (2020). Pengaruh Penerapan Model Pembelajaran Means Ends Analysis terhadap Kemampuan Menalar Deduktif Mahasiswa Ditinjau dari Kemampuan Representasi Matematis. Journal of Medives: Journal of Mathematics Education IKIP Veteran Semarang, 4(1), 151-160. 


\section{PENDAHULUAN}

Dosen yang baik akan selalu mempersiapkan rancangan pelaksanaan pembelajaran yang optimal agar mahasiswa yang diajarnya memperoleh hasil yang maksimal dari terlaksananya pembelajaran yang terencana dengan sempurna. Pembuatan rencana pelaksanaan pembelajaran yang baik haruslah memperhatikan kesesuaian antara materi yang akan disampaikan dengan metode pembelajaran yang akan digunakan, antara materi dengan media yang akan dipakai, antara materi dengan alat evaluasinya, dan alokasi waktu yang efektif untuk pelaksanaannya.

Rencana pelaksanaan pembelajaran khususnya dalam pembelajaran matematika biasanya menggunakan langkahlangkah yang rutin yaitu diawali dengan pemberian materi atau penjelasan materi dari dosen, dilanjutkan dengan pemberian contoh-contoh soal hingga cara menjawabnya dan kemudian diakhiri dengan mahasiswa mengerjakan soalsoal latihan yang diberikan oleh dosen. Gambaran ini adalah deskripsi tentang pelaksanaan pembelajaran yang konvensional dengan metode ekspositori. Dosen yang aktif, sementara mahasiswa cukup dengan menyimak dan mengerti materi yang disampaikan oleh dosen. Dosen merasa sudah berhasil, jika mahasiswa sudah dapat menyelesaikan soal-soal yang diberikan oleh dosen di akhir pembelajaran. Padahal jawaban mahasiswa yang merupakan langkah rutin, kadang hanya meniru langkah-langkah yang dicontohkan oleh dosen.

Kemampuan mahasiswa dalam menyelesaikan soal-soal matematika, khususnya soal esai, harusnya berkenaan dengan kemampuan pemahaman konsep, kemampuan pemecahan masalah, kemampuan komunikasi matematis, kemampuan menalar deduktif, kemampuan berpikir kreatif, hingga kemampuan menalar deduktif. Kemampuan menalar deduktif diperlukan untuk menyelesaikan soal-soal matematika yang lebih khusus, yaitu berbentuk esai dengan langkah-langkah penyelesaian yang tidak rutin. Kemampuan menalar deduktif memerlukan kemampuan untuk merangkai logika secara deduktif, merangkai langkah-langkah pembuktian secara sistematis, hingga sampai kepada bentuk formula yang harus dibuktikan.

Kemampuan menalar deduktif adalah dimilikinya kompetensi dalam berpikir secara logis dan sistematis, sehingga mampu memahami bahwa masalah matematika yang secara umum sebenarnya terjadi dari hal-hal yang khusus. Kemampuan menalar deduktif ini harus dilatih dan dijadikan sebagai pembiasaan bagi mahasiswa. Adapun kemampuan lainnya yang dibutuhkan untuk dapat memiliki kemampuan bernalar secara deduktif adalah kemampuan merepresentasikan matematika, yaitu kemampuan yang berkaitan dengan kemampuan komunikasi dan pemahaman konsep.

Gagne dan Mayer dalam Hwang (2007) menyatakan bahwa kemampuan representasi yang baik adalah kunci untuk mendapatkan solusi yang tepat dalam pemecahan masalah dan bernalar. Elliot dan Kenney (2001) mengungkapkan bahwa penggunaan berbagai representasi diperlukan ketika membaca, menulis, mendiskusikan, menjelaskan, dan mengklarifikasi penalaran matemati- 
ka dalam mengomunikasikan matematika. Selain berkaitan dengan komunikasi dan pemahaman, representasi juga sangat berkaitan dengan pemecahan masalah, (Hudiono, 2005: 79-82). Oleh karena itu, dapat dikatakan bahwa kemampuan representasi matematis menunjang kemampuan komunikasi, pemahaman, pemecahan masalah matematis, dan bernalar khususnya bernalar secara deduktif.

Kemampuan representasi matematis mahasiswa dapat dilihat melalui bagaimana cara mahasiswa mengungkapkan ide, gagasan, dan pemikiran matematika melalui gambar, bangun geometri, tabel, diagram, grafik, simbol, persamaan matematika, verbal atau katakata, maupun benda konkrit. Indikator kemampuan representasi matematis dibedakan menjadi tiga jenis, yaitu 1) representasi visual, berupa gambar, bangun geometri, benda konkrit, tabel, diagram, dan grafik, 2) representasi ekspresi matematis, berupa simbol-simbol dan persamaan matematika, dan 3) representasi verbal, berupa kata-kata dan kalimat-kalimat (Handayani, 2016: 21).

Kemampuan representasi termasuk dalam salah satu kompetensi dasar matematika yang harus dimiliki oleh mahasiswa. Hal ini sesuai dengan pernyataan NCTM tahun 2000 yang menjelaskan bahwa 5 (lima) kompetensi dasar matematika yang harus dimiliki oleh mahasiswa di antaranya adalah kemampuan pemecahan masalah (problem solving), kemampuan penalaran (reasoning and proof), kemampuan komunikasi matematis (mathematical communication), kemampuan koneksi matematis (mathematical connections), dan kemampuan representasi matematis (mathematical representation). Berdasarkan pernyataan tersebut, dapat ditegaskan bahwa kemampuan representasi dan kemampuan bernalar perlu mendapat perhatian khusus dalam proses pembelajaran matematika.

Untuk mencapai hasil pembelajaran yang diinginkan, maka diperlukan metode pembelajaran yang tepat untuk dapat menanamkan kemampuan menalar deduktif. Metode pembelajaran yang dapat menumbuh kembangan kemampuan menalar antara lain adalah metode Means Ends Analysis (MEA). Menurut Ngalimun (2014) metode MEA adalah metode pembelajaran variasi yang menyajikan pemecahan masalah. Langkah-langkah metode MEA terbagi atas menyajikan materi pemecahan masalah, mengelaborasi masalah menjadi sub-sub masalah yang sederhana, mengidentifikasi perbedaan, menyusun sub-sub masalah agar terjadi suatu hubungan, dan memilih strategi yang tepat.

Dari paparan yang dijabarkan di atas, terdapat beberapa permasalahan yang memerlukan penyelesaian dalam bentuk penelitian yang berkesinambungan. Kemampuan penalaran, khususnya kemampuan menalar deduktif yang tidak maksimal pada diri mahasiswa memerlukan metode pembelajaran yang tepat agar mahasiswa tetap merasa tertantang untuk menyelesaikan soal-soal yang menggunakan langkah penyelesaian yang tidak rutin. Belum diterapkannya metode pembelajaran yang membuat mahasiswa mampu menalar secara deduktif untuk memecahkan masalah dengan memilah-milah masalah menjadi 
sub-sub masalah, sehingga soal yang cukup kompleks dapat diselesaikan secara sistematis dan logis. Dosen masih menggunakan metode pembelajaran konvensional, sehingga penerapan metode MEA diharapkan dapat membentuk kemampuan penalaran pada mahasiswa, karena dalam metode ini terdapat langkah-langkah yang diperlukan agar kemampuan menalar mahasiswa secara deduktif dapat diasah dengan optimal. Selama ini, kemampuan representasi matematis belum diperhatikan oleh dosen pada saat melaksanakan pembelajaran matematika di kelas terutama pada perkuliahan Geometri Euclid. Padahal kemampuan representasi matematis ini sangat diperlukan dalam menumbuhkembangkan kemampuan menalar deduktif.

Berdasarkan paparan di atas, maka dalam penelitian dilakukan untuk mengetahui apakah terdapat pengaruh penerapan metode pembelajaran MEA terhadap kemampuan menalar deduktif mahasiswa pada mata kuliah Geometri Euclid ditinjau dari kemampuan representasi matematis mahasiswa. Penelitian dilakukan pada program studi Pendidikan Matematika FMIPA UNJ.

\section{METODE PENELITIAN}

Metode penelitian yang digunakan pada penelitian ini adalah metode quasi experiment dengan desain penelitian adalah Posttest-Only Control Group Design. Sugiyono (2015) menyatakan bahwa metode penelitian eksperimen merupakan metode penelitian yang digunakan untuk mencari pengaruh perlakuan (variabel bebas) terhadap variabel tertentu (variabel terikat) dalam kondisi yang terkendalikan. Variabel bebas pada penelitian ini adalah model pembelajaran MEA. Variabel terikat adalah kemampuan menalar deduktif. Variabel kontrol adalah kemampuan representasi matematis (KRM). Sedangkan pengambilan data menggunakan instrumen tes kemampuan representasi matematis, tes kemampuan menalar deduktif, teknik analisis data menggunakan two-way ANOVA. Uji ANOVA 2 Arah akan menghasilkan kesimpulan ada tidaknya perbedaan kemampuan menalar deduktif, maupun ada tidaknya interaksi antara model pembelajaran dan kemampuan representasi matematis terhadap kemampuan menalar deduktif.

Objek penelitian sebagai populasi dalam penelitian adalah seluruh mahasiswa program studi pendidikan matematika FMIPA UNJ yang mengambil mata kuliah geometri euclid berjumlah 117 mahasiswa. Teknik yang digunakan dalam pengambilan sample adalah multistage random sampling. Dari mahasiswa yang dipilih menjadi objek penelitian dibagi menjadi dua kelas, satu kelas diambil sebagai kelas eksperimen dan satu kelas yang lain sebagai kelas kontrol. Pada kelas eksperimen diberikan perlakuan yaitu model pembelajaran MEA, sedangkan pada kelas kontrol menggunakan pembelajaran konvensional. Pada akhir penelitian, semua mahasiswa di dua kelas terpilih, akan diberikan tes yang sama yaitu tes kemampuan menalar deduktif. Desain penelitian PosttestOnly Control Group Design yang digunakan dapat dilihat pada Tabel 1 . 
Tabel 1 Desain Penelitian

\begin{tabular}{ccc}
\hline Kelompok & Treatment & Posttest \\
\hline $\mathrm{E}(\mathrm{R})$ & $\mathrm{X}$ & $\mathrm{O}$ \\
$\mathrm{C}(\mathrm{R})$ & - & $\mathrm{O}$
\end{tabular}

Keterangan:

E : Kelompok eksperimen

C : Kelompok kontrol

$\mathrm{R}$ : Kelompok eksperimen dan kontrol dipilih secara random

X : Perlakuan model MEA yang diberikan pada kelompok eksperimen

$\mathrm{O}$ : Posttest diberikan pada kelas eksperimen dan kontrol.

Kerangka penelitian yang menunjukkan keterkaitan antara model pembelajaran dan kemampuan representasi matematis terhadap kemampuan menalar deduktif mahasiswa dideskripsikan dengan menggunakan desain eksperimen faktorial Treatment by Level $2 \mathrm{x}$ 2 design, seperti yang ditunjukkan pada Tabel 2.

Tabel 2. Desain Penelitian dengan Faktorial

Level 2 x 2 Keterkaitan Model Pembelajaran dan Kemampuan Representasi Matematis terhadap Kemampuan Menalar Deduktif

\begin{tabular}{ccc}
\hline Kemampuan & \multicolumn{3}{c}{ Model Pembelajaran (A) } \\
Representasi & MEA & Konvensional \\
Matematis (B) & $\left(\mathbf{A}_{1}\right)$ & $\left.\mathbf{( A}_{2}\right)$ \\
\hline Tinggi $\left(\mathrm{B}_{1}\right)$ & $\mathrm{A}_{1} \mathrm{~B}_{1}$ & $\mathrm{~A}_{2} \mathrm{~B}_{1}$ \\
Rendah $\left(\mathrm{B}_{2}\right)$ & $\mathrm{A}_{1} \mathrm{~B}_{2}$ & $\mathrm{~A}_{2} \mathrm{~B}_{2}$ \\
\hline
\end{tabular}

Keterangan:

A : Model pembelajaran yang digunakan dalam penelitian

B : Kemampuan representasi matematis (KRM) mahasiswa yang diperoleh berdasarkan skor hasil tes kemampuan representasi matematis

$\mathrm{A}_{1}$ : Kelompok mahasiswa yang diajar menggunakan model pembelajaran MEA

$\mathrm{A}_{2}$ : Kelompok mahasiswa yang diajar menggunakan pembelajaran konvensional

$\mathrm{B}_{1}$ : Kelompok mahasiswa yang memiliki kemampuan representasi matematis tinggi
$\mathrm{B}_{2}$ : Kelompok mahasiswa yang memiliki kemampuan representasi matematis rendah

$\mathrm{A}_{1} \mathrm{~B}_{1}$ : Kemampuan menalar deduktif mahasiswa yang memiliki kemampuan representasi matematika tinggi yang diajar menggunakan model pembelajaran MEA

$\mathrm{A}_{2} \mathrm{~B}_{1}$ : Kemampuan manalar deduktif mahasiswa yang memiliki kemampuan representasi matematis tinggi yang diajar menggunakan pembelajaran konvensional

$\mathrm{A}_{1} \mathrm{~B}_{2}$ : Kemampuan menalar deduktif mahasiswa yang memiliki kemampuan representasi matematis rendah yang diajar menggunakan model pembelajaran MEA

$\mathrm{A}_{2} \mathrm{~B}_{2}$ : Kemampuan menalar deduktif mahasiswa yang memiliki kemampuan representasi matematis rendah yang diajar menggunakan pembelajaran konvensional

Pengumpulan data dalam penelitian ini dilakukan dengan instrumen tes, dimana instrumen tes terbagi atas tes kemampuan representasi matematis dan tes kemampuan menalar deduktif yang digunakan untuk mengumpulkan data hasil kemampuan menalar deduktif mahasiswa. Sebelum instrumen penelitian digunakan untuk mengumpulkan data, perlu diketahui sejauh mana taraf validitas dan reliabilitasnya.

Hipotesis statistik yang akan diuji dalam penelitian ini adalah sebagai berikut.

Hipotesis 1, $H_{0}: \mu_{A_{1}} \leq \mu_{A_{2}}$ $H_{1}: \mu_{A_{1}}>\mu_{A_{2}}$

Hipotesis $2, H_{0}: I N T A \times B=0$

$$
H_{1}: I N T A \times B \neq 0
$$

Hipotesis 3, $H_{0}: \mu_{A_{1} B_{1}} \leq \mu_{A_{2} B_{1}}$

$$
H_{1}: \mu_{A_{1} B_{1}}>\mu_{A_{2} B_{1}}
$$

Hipotesis 4, $H_{0}: \mu_{A_{1} B_{2}} \geq \mu_{A_{2} B_{2}}$

$$
H_{1}: \mu_{A_{1} B_{2}}<\mu_{A_{2} B_{2}}
$$


Keterangan:

C : Model pembelajaran yang digunakan dalam penelitian

$B \quad$ : Kemampuan representasi matematika mahasiswa yang diperoleh berdasarkan skor hasil tes kemampuan awal.

$\mu_{A_{1}} \quad$ : Rata-rata nilai kemampuan menalar deduktif kelompok mahasiswa yang diajar menggunakan model pembelajaran MEA.

$\mu_{A_{2}} \quad$ : Rata-rata nilai kemampuan menalar deduktif kelompok mahasiswa yang diajar menggunakan pembelajaran konvensional.

$\mu_{A_{1} B_{1}}:$ Rata-rata nilai kemampuan menalar deduktif mahasiswa yang memiliki kemampuan representasi matematis tinggi yang diajar menggunakan model pembelajaran MEA.

$\mu_{A_{2} B_{1}}$ : Rata-rata nilai kemampuan menalar deduktif mahasiswa yang memiliki kemampuan representasi matematis tinggi yang diajar menggunakan pembelajaran konvensional.

$\mu_{A_{1} B_{2}}$ : Rata-rata nilai kemampuan menalar deduktif mahasiswa yang memiliki kemampuan representasi matematis rendah yang diajar menggunakan model pembelajaran MEA

$\mu_{A_{2} B_{2}}$ : Rata-rata nilai kemampuan menalar deduktif yang memiliki kemampuan representasi matematis rendah yang diajar menggunakan pembelajaran konvensional.
Teknik analisis data yang digunakan dalam penelitian ini adalah analisis variansi dua arah (ANAVA Dua Arah). Teknik analisis ANAVA Dua Arah dapat digunakan untuk menguji perbedaan kemampuan menalar deduktif antara mahasiswa yang diajar dengan menggunakan model pembelajaran MEA dan pembelajaran konvensional. Analisis variansi dua arah juga dapat digunakan untuk menguji ada tidaknya interaksi antara model pembelajaran dan kemampuan representasi matematis terhadap kemampuan menalar deduktif. Alur teknik analisis data selengkapnya disajikan pada Gambar 1 .

Teknik analisis ANAVA Dua Arah digunakan untuk menguji perbeda-an kemampuan menalar deduktif antara mahasiswa yang diajar dengan menggunakan model pembelajaran MEA dan pembelajaran konvensional yaitu pembelajaran langsung pada kelas kontrol. Analisis variansi dua arah juga dapat digunakan untuk menguji ada tidaknya interaksi antara model pembelajaran dan kemampuan representasi matematis terhadap kemampuan menalar deduktif. Agar pengujian hipotesis dapat dilakukan, maka perlu dilakukan uji prasyarat analisis yaitu uji normalitas dan homogenitas data. Uji normalitas menggunakan uji Liliefors, uji homogenitas menggunakan uji Lavene dengan bantuan SPSS-22, dan uji ANAVA dengan taraf signifikansi $\alpha$ sebesar 0,05 .

Hipotesis uji yang diajukan adalah sebagai berikut.

a. $\mathrm{H}_{0}=$ Tidak ada pengaruh perbedaan model

$\mathrm{H}_{1}=$ Ada pengaruh perbedaan model 


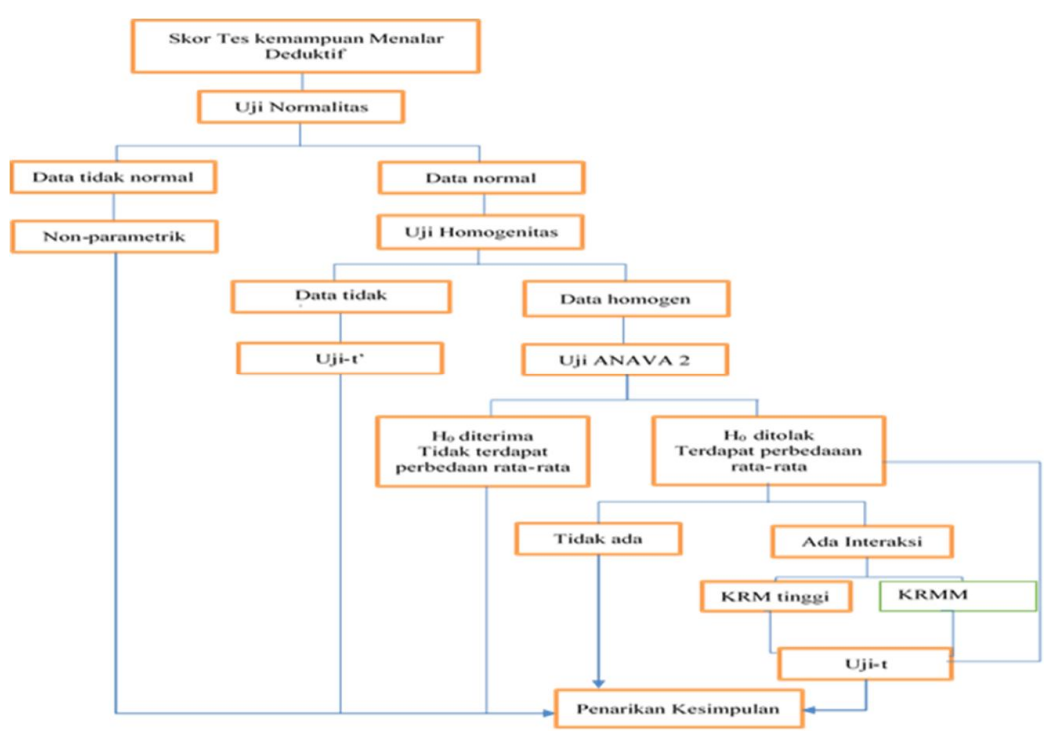

Gambar 1. Teknik Analisis Data

b. $\mathrm{H}_{0}=$ Tidak ada interaksi antara model dengan RPM

$\mathrm{H}_{1}=$ Ada interaksi antara model dengan RPM

Kriteria Uji : Terima $\mathrm{H}_{0}$ jika nilai Sig. $>$ 0,05 dan tolak $\mathrm{H}_{0}$ jika nilai Sig. $\leq 0,05$.

Untuk mengetahui perbedaan ratarata kemampuan menalar deduktif antara kelompok mahasiswa yang diajar dengan menggunakan model pembelajaran MEA dengan mahasiswa yang diajar dengan menggunakan pembelajaran konvensional, perbedaan rata-rata kemampuan menalar deduktif pada kelompok mahasiswa yang memiliki kemampuan representasi matematis tinggi atau rendah, dalam penelitian ini dilakukan dengan menggunakan uji-t. Perhitungan uji-t dilakukan dengan menggunakan SPSS-23 pada taraf signifikansi $\alpha=0,05$.

Hipotesis uji-t yang diajukan:

a. $\mathrm{H}_{0}: \mu_{1} \leq \mu_{2}$ (rata-rata nilai kel. 1 lebih rendah atau sama dengan kel.2)
$\mathrm{H}_{1}: \mu_{1}>\mu_{2}$ (rata-rata nilai kel. 1 lebih tinggi dari rata-rata nilai kel.2)

b. $\mathrm{H}_{0}: \mu_{1} \geq \mu_{2}$ (rata-rata nilai kel. 1 lebih tinggi atau sama dengan kel.2) $\mathrm{H}_{1}: \mu_{1}<\mu_{2}$ (rata-rata nilai kel. 1 lebih rendah dari rata-rata nilai kel.2)

Kriteria Uji Hipotesis:

a. Tolak $\mathrm{H}_{0}$ jika $t_{\text {hitung }} \geq \mathrm{t}_{\text {tabel}}$, dan terima $\mathrm{H}_{0}$ jika $\mathrm{t}_{\text {hitung }}<\mathrm{t}_{\text {tabel. }}$.

b. Tolak $\mathrm{H}_{0}$ jika $\mathrm{t}_{\text {hitung }} \leq-\mathrm{t}_{\text {tabel}}$, dan terima $\mathrm{H}_{0}$ jika $t_{\text {hitung }}>-\mathrm{t}_{\text {tabel }}$.

\section{HASIL DAN PEMBAHASAN}

Berdasarkan uji normalitas dan homogenitas data yang telah dilakukan, diketahui bahwa semua kelompok data hasil penelitian yaitu data kemampuan representasi matematis, data kemampuan menalar deduktif berdistribusi normal dan homogen. Sebelum dilakukan uji hipotesis, dilakukan uji ANAVA dua arah (two-way ANAVA) untuk mengetahui ada tidaknya pengaruh model pembelajaran terhadap kemampuan menalar deduktif, pengaruh interaksi 
kemampuan representasi matematis dan model pembelajaran terhadap kemampuan menalar deduktif. Jika dari hasil uji ANAVA dua arah terdapat interaksi maka dilanjutkan dengan uji-t untuk mengetahui perbedaan nilai rata-rata antara kelompok data.

\section{Perbedaan Kemampuan Menalar Deduktif Mahasiswa Berdasarkan Jenis Pembelajaran}

Dari hasil bahwa pengujian ANAVA dua arah untuk mengetahui perbedaan kemampuan menalar deduktif mahasiswa berdasarkan jenis pembelajaran didapatkan bahwa nilai signifikansi sebesar 0,013 atau kurang dari 0.05. Maka $\mathrm{H}_{0}$ ditolak, sehingga dapat disimpulkan bahwa terdapat pengaruh perbedaan model pembelajaran yang signifikan terhadap kemampuan menalar deduktif mahasiswa. Selanjutnya, dilakukan uji-t untuk mengetahui perbedaan nilai rata-rata kemampuan menalar deduktif. Dari asil uji-t diperoleh nilai $t_{\text {hitung }}=2,866$ dan $t_{\text {tabel }}=1,66277$ pada taraf signifikansi $\alpha=0,05 \mathrm{dan} \mathrm{dk}=86$. Karena $t_{\text {hitung }}>\mathrm{t}_{\text {tabel }}$ maka $\mathrm{H}_{0}$ ditolak. Hal ini berarti bahwa kemampuan menalar deduktif mahasiswa yang mendapat perlakuan model pembelajaran MEA lebih tinggi dibanding mahasiswa yang diajar dengan pembelajaran konvensional. Perbedaan rata-rata kemampuan menalar deduktif antara mahasiswa yang mendapat perlakuan model pembelajaran MEA dan mahasiswa yang diajar dengan pembelajaran konvensional sebesar 1,136.
Interaksi antara Model Pembelajaran dan Kemampuan Representasi Matematis terhadap Kemampuan Menalar Deduktif

Hasil pengujian ANAVA dua arah untuk mengetahui interaksi antara model pembelajaran dan kemampuan representasi matematis terhadap kemampuan menalar deduktif menunjukkan bahwa interaksi antara kemampuan representasi matematis dan model pembelajaran memiliki nilai signifikansi sebesar $0,011<\alpha=0,05$. Maka $\mathrm{H}_{0}$ ditolak, sehingga dapat disimpulkan bahwa interaksi model pembelajaran dan kemampuan representasi matematis secara signifikan berpengaruh terhadap kemampuan menalar deduktif mahasiswa. Secara keseluruhan kemampuan menalar deduktif mahasiswa yang diajar dengan model pembelajaran MEA lebih tinggi dibanding mahasiswa yang diajar dengan pembelajaran konvensional. Interaksi tersebut juga menunjukkan perbedaan nilai rata-rata yang sangat signifikan pada kelompok mahasiswa dengan kemampuan representasi matematis tinggi (MEA lebih dari 13,5 dan DI sekitar 11,5). Hal ini berarti bahwa model pembelajaran MEA efektif digunakan pada kelompok mahasiswa dengan kemampuan kemampuan representasi matematis tinggi. Berdasarkan penjelasan di atas, dapat disimpulkan bahwa terdapat interaksi yang signifikan antara model pembelajaran dan kemampuan representasi matematis terhadap kemampuan menalar deduktif. 


\section{Kemampuan Menalar Deduktif pada Kelompok Mahasiswa yang memiliki Kemampuan Representasi Matematis Tinggi}

Hasil uji hipotesis menyimpulkan bahwa model pembelajaran dan kemampuan representasi matematis berpengaruh secara signifikan terhadap kemampuan menalar deduktif. Selanjutnya akan dilakukan uji-t terhadap data kemampuan menalar deduktif kelompok mahasiswa kemampuan representasi matematis tinggi untuk menguji hipotesis 3 yaitu kemampuan menalar deduktif kelompok mahasiswa dengan kemampuan representasi matematis tinggi yang mendapat perlakuan model pembelajar MEA $\left(\mathrm{A}_{1} \mathrm{~B}_{1}\right)$ akan lebih tinggi dibanding mahasiswa yang diajar dengan pembelajaran konvensional $\left(\mathrm{A}_{2} \mathrm{~B}_{1}\right)$. Berdasarkan hasil uji-t, diperoleh nilai $t_{\text {hitung }}=3,814$ dan niai $t_{\text {tabel }}$ $=1,682$ pada taraf signifikansi $\alpha=0,05$ dan $\mathrm{dk}=42$. Karena kriteria penerimaan $\mathrm{H}_{0}$ adalah $\mathrm{t}_{\text {hitung }}<\mathrm{t}_{\text {tabel }}$ dan hasil uji thitung $>$ tabel maka $\mathrm{H}_{0}$ ditolak. Sehingga dapat disimpulkan bahwa kemampuan menalar deduktif kelompok mahasiswa dengan kemampuan representasi matematis tinggi yang mendapat perlakuan model pembelajaran MEA lebih tinggi dibanding mahasiswa yang diajar dengan pembelajaran konvensional.

\section{Kemampuan Menalar Deduktif pada Kelompok Mahasiswa yang Memiliki Kemampuan Representasi Matematis Rendah}

Hipotesis keempat yang akan diuji adalah kemampuan menalar deduktif kelompok mahasiswa dengan kemampuan representasi matematis rendah yang mendapat perlakuan model pembelajaran MEA $\left(\mathrm{A}_{1} \mathrm{~B}_{2}\right)$ akan lebih rendah dibanding mahasiswa yang diajar dengan pembelajaran konvensional $\left(\mathrm{A}_{2} \mathrm{~B}_{2}\right)$. Hasil uji-t menunjukkan bahwa nilai $\mathrm{t}_{\text {hitung }}=0,372$ dan niai $-\mathrm{t}_{\text {tabel }}=$ $-1,682$ pada taraf signifikansi $\alpha=0,05$ dan $\mathrm{dk}=42$. Karena kriteria penolakan $\mathrm{H}_{0}$ adalah nilai $\mathrm{t}_{\text {hitung }}<-\mathrm{t}_{\text {tabel }}$ dan hasil uji $t_{\text {hitung }}>-t_{\text {tabel }}$ maka $\mathrm{H}_{0}$ diterima, artinya kemampuan menalar deduktif matematis kelompok mahasiswa yang memiliki kemampuan representasi matematis rendah yang diajar dengan model pembelajaran MEA lebih rendah dibanding mahasiswa yang diajar dengan pembelajaran konvensional. Nilai signifikansi data kemampuan menalar deduktif antara kedua kelompok mahasiswa sebesar $0,012<\alpha=0,05$. Hal ini berarti bahwa ada perbedaan kemampuan menalar deduktif yang signifikan pada kelompok mahasiswa dengan kemampuan representasi matematis rendah.

\section{KESIMPULAN}

Dari hasil analisis data dan pengujian hipotesis yang telah dilakukan dapat diambil beberapa kesimpulan sebagai berikut. 1) Kemampuan menalar deduktif mahasiswa yang diajar dengan model pembelajaran matematika MEA secara keseluruhan lebih tinggi dibanding dengan mahasiswa yang diajar dengan pembelajaran konvensional. 2) Terdapat interaksi antara model pembelajaran dan kemampuan awal representasi matematis mahasiswa yang berpengaruh secara signifikan terhadap kemampuan menalar deduktif. 3) Kemampuan menalar deduktif kelompok 
mahasiswa dengan kemampuan representasi matematis tinggi yang diajar dengan model pembelajaran matematika MEA lebih tinggi dibanding yang diajar dengan pembelajaran konvensional. 4) Terdapat perbedaan yang signifikan pada kemampuan menalar deduktif kelompok mahasiswa dengan kemampuan representasi matematis rendah antara mahasiswa yang diajar dengan model pembelajaran matematika MEA dan mahasiswa yang diajar dengan pembelajaran konvensional.

\section{DAFTAR PUSTAKA}

Amalia, Rizky dan Yulianti, Isti. 2015. "Penerapan Pendekatan Problem Posing Untuk Meningkatkan Kemampuan Representasi Visual Matematis Mahasiswa SMP." Seminar Nasional Matematika dan Pendidikan Matematika FMIPA $U N Y$. Yogyakarta: UNY.

Bani, Asmar. 2012. "Pemecahan Masalah dan Representasi Pembelajaran MAtematika." Jurnal Matematika dan Pendidikan Matematika, Delta-Pi.

Cuoco, Albert A. 2001. The Roles of Representation in School Mathematics 2001 Yearbook. Reston VA: NCTM.

Handayani, Rika. 2016. "Pengaruh Model Pembelajaran Generatif Terhadap Kemampuan Representasi MAtematis dan Self Efficacy Mahasiswa," Tesis. Jakarta: FMIPA UNJ.

Huda, Miftahul. 2014. Model-model Pengajaran dan Pembelajaran. Yogyakarta: Pustaka Pelajar.

Hudiono, Bambang. 2005. "Peran Pembelajaran Diskursus Multi Representasi Terhadap
Pengembangan Kemampuan Matematik dan Daya Representasi Pada Mahasiswa," Disertasi. Bandung: Universitas Pendidikan Indonesia.

Hwang, W.Y., Chen, N.S., and Dung, J.J., et al. 2007. "Multiple Representation Skills and Creativity Effects on Mathematical Problem Solving Using a Meultimedia Whiteboard System," Educational Technology and Society, Taiwan.

Kartini. 2009. "Peranan Representasi Dalam Pembelajaran Matematika," Seminar Nasional Matematika dan Pendidikan Matematika FMIPA $U N Y$. Yogyakarta: UNY.

Lestari, Karunia E. dan Yudhanegara M. Ridwan. 2015. Penelitian Pendidikan Matematika. Bandung: PT Refika Aditama.

National Council of Teacher of Mathematics. 2000. Standards 2000: Principle and Standars for School Mathematics. Reston VA: The National Council of Teacher of Mathematics Inc.

Napitupulu, $\quad$ E.E. 2016. "Mengembangkan Kemampuan Menalar dan Memecahkan Masalah Melalui Pembelajaran Berbasis Masalah (PBM)." Online. https://www.researchgate.net/publ ication/311322537. (Diakses 20 Apr 2018).

Ngalimun. 2014. Strategi dan Model Pembelajaran. Banjarmasin: Aswaja Pressindo.

Sudjana. 2005. Metode Statistika. Bandung: Tarsito.

Sugiyono. 2015. Metode Penelitian Pendidikan Pendekatan Kuantitatif, Kualitatif, dan $R \& D$. Bandung: Alfabeta. 